UDC $546.05 ; 546.655 ; 661.491$

A.M. Grinko ${ }^{a, b}$, A.V. Brichka ${ }^{b}$, O.M. Bakalinska ${ }^{b}$, O.I. Oranska ${ }^{b}$, M.T. Kartel ${ }^{b}$

\title{
KAOLIN/CERIUM OXIDE NANOCOMPOSITES: PROPERTIES AND ACTIVITY IN HYDROGEN PEROXIDE DECOMPOSITION REACTION
}

\author{
a National University of «Kyiv-Mohyla Academy», Kyiv, Ukraine \\ ${ }^{b}$ Chuiko Institute of Surface Chemistry of the National Academy of Sciences of Ukraine, Kyiv, Ukraine
}

\begin{abstract}
A number of kaolin-based nanomaterials decorated with $\mathrm{CeO}_{2}$ were synthesized by the precipitation method from aqueous solutions of cerium nitrate, without stabilizers at room temperature, and their properties were characterized. The amount of nanoceria deposited in nanomaterials was $2.76-7.37 \%$, and their size varied from $5.6 \mathrm{~nm}$ to $10.4 \mathrm{~nm}$. X-ray diffraction analysis of the samples showed that cerium dioxide has a cubic structure. IR spectroscopy confirmed that a chemical interaction between the modifier and the matrix (i.e. the formation of a chemical bond) cannot be detected. The $\mathrm{Ce}^{4+} / \mathrm{Ce}^{3+}$ ratio in nanocomposites was estimated from UV-spectra of diffuse reflectance, it varied in the range of 0.98 to 2.88 . By calculating the affinity constant from kinetic data in the framework of enzymatic reactions concept, the catalytic activity of the synthesized materials and kaolin in the model reaction of hydrogen peroxide decomposition was determined in the $\mathrm{pH}$ range of 8.5-10.5 and compared with the catalase enzyme and commercial nanosized $\mathrm{CeO}_{2}$. The $\mathrm{pH}$ dependence of the nanocomposites activity was shown to be extreme with maxima at $\mathrm{pH}$ 10.0. The activation energy of the reaction of hydrogen peroxide decomposition on the studied catalysts was determined for the temperature range of $20^{\circ} \mathrm{C}$ to $40^{\circ} \mathrm{C}$ at $\mathrm{pH} 10.0$. It was found that the catalytic activity of nanocomposites increased and the activation energy decreased with an increase in the decorator content at a constant $\mathrm{pH}$. An analysis of the factors that determine the activity of nanoceria in the nanocomposites showed that an increase in the dispersion of nanocrystallites and the relative content of $\mathrm{Ce}^{3+}$ ions on their surface resulted in the improvement in the catalytic activity of nanomaterials.
\end{abstract}

Keywords: cerium oxide nanoparticles, kaolin, nanocomposites, catalytic activity, activation energy, hydrogen peroxide decomposition.

DOI: $10.32434 / 0321-4095-2020-130-3-59-68$

\section{Introduction}

Cerium, the most common rare earth element, is non-toxic, relatively inexpensive, and available for research and practical use. Cerium electronic configuration is [Xe] $4 \mathrm{f}^{1} 5 \mathrm{~d}^{1} 6 \mathrm{~s}^{2}$. The energy of the inner $4 \mathrm{f}$ level is almost equal to the energy of the outer or valence electrons. Since very low energy is required to change the relative occupancy of these electronic levels, and the orbitals $4 \mathrm{f}$ and $5 \mathrm{~d}$ are partially filled, cerium atoms exhibit double valence states +4 and +3 , forming two oxide compounds: $\mathrm{CeO}_{2}\left(\mathrm{Ce}^{4+}\right)$ and $\mathrm{Ce}_{2} \mathrm{O}_{3}\left(\mathrm{Ce}^{3+}\right)$.

The transition from an ion $\mathrm{Ce}^{4+}$ with a smaller ionic radius $(0.92 \AA)$ to an ion $\mathrm{Ce}^{3+}$ with a larger radius $(1.034 \AA)$ leads to the formation of oxygen vacancies. The reduction of the particle size of the $\mathrm{CeO}_{2}$ crystals to the nanoscale results in an expansion of the lattice and an increase in the ability to accumulate oxygen. The amount of $\mathrm{Ce}^{3+}$ ions increases, consequently the deficiency of oxygen in the structure and on the surface of the particles causes the formation of more surface defects (as compared with larger crystals) [1]. The existence of oxygen vacancies and their mobility in the crystal facilitate redox reactions on its surface, where nanoceria effectively binds free radicals [2], which include reactive oxygen species (ROS), such as superoxide anion radical $\left({ }^{\circ} \mathrm{O}_{2}^{-}\right)$, singlet oxygen $\left({ }^{1} \mathrm{O}_{2}\right)$, hydroxyl $\left(\mathrm{OH}^{\bullet}\right)$ and peroxide $\left(\mathrm{HO}_{2}{ }^{*}\right)$ radicals, hydrogen peroxide $\left(\mathrm{H}_{2} \mathrm{O}_{2}\right)$, and peroxide ion $\left(\mathrm{HO}_{2}^{-}\right)$. 
Superoxide anion-radical is generated as a byproduct of metabolic processes and is capable of decomposing to hydrogen peroxide by itself or by enzyme. The rate of the enzymatic reaction is about four orders of magnitude higher than the spontaneous one. In addition, in spontaneous dismutation, the product of the reaction is singlet oxygen, while the enzymatic reaction leads to the formation of oxygen in the triplet state. A further protonation of hydrogen peroxide results in formation of a hydroxyl radical, which has higher reactivity and toxicity than the superoxide anion radical.

To limit the concentration of superoxide anion and hydroxyl radical and restore them to water in cells, enzymes (superoxide dismutase and catalase, respectively) are produced. However, due to adverse factors, such as inflammation, these protective mechanisms do not always work correctly, leading to an increase in the reactive oxygen species. In addition, the functioning of natural enzymes is limited because they are effective only in a certain limited $\mathrm{pH}$ range, sensitive to temperature changes and dependent on the salt content of the solution. It has been shown [3] that nanoceria is capable of exhibiting catalytic enzymatic (superoxide dismutase and catalase) properties, making them a potent antioxidant agent for therapeutic applications. The biological activity of nanosized $\mathrm{CeO}_{2}$ (the ability to bind, retain and release ROS) depends on many factors, including the size of the particles, their morphology [4], the $\mathrm{pH}$ of the medium [5] and the number of surface defects, which are defined as the ratio of the number of $\mathrm{Ce}^{4+} / \mathrm{Ce}^{3+}$ atoms [6].

This work was aimed at preparing nanocomposites «kaolin/cerium oxide» with different modifier content, analyzing their physicochemical properties, determining the catalytic enzyme activity of the synthesized materials in a model reaction of hydrogen peroxide decomposition in comparison with the activity of nanoceria, kaolin and catalase enzyme at different $\mathrm{pH}$ medium, and establishing the effective activation energy of the reaction of hydrogen peroxide decomposition by synthesized nanocomposites, pristine kaolin and nanoceria.

\section{Materials and methods}

Nanoceria was synthesized by reacting cerium nitrate with sodium hydroxide in an aqueous medium without any stabilizers at room temperature:

$4 \mathrm{Ce}\left(\mathrm{NO}_{3}\right)_{3}+12 \mathrm{NaOH}+\mathrm{O}_{2}=4 \mathrm{CeO}_{2}+12 \mathrm{NaNO}_{3}+6 \mathrm{H}_{2} \mathrm{O}$

Dysten Limited's P-2 brand kaolin $\left.\left(\mathrm{Al}_{2} \mathrm{Si}_{2} \mathrm{O}_{5}(\mathrm{OH})_{4}\right)\right)$ was used. The nanocomposite suspension was filtered, washed and dried at $383^{\circ} \mathrm{C}$.
The samples of kaolin/ $\mathrm{CeO}_{2}$ were synthesized with different weight content of nanoceria in nanocomposites: $3 \%(\mathrm{~K}-3 \mathrm{Ce}), 5 \%(\mathrm{~K}-5 \mathrm{Ce}), 7 \%$ (K-7Ce) and 9\% (K-9Ce). Nano-sized cerium dioxide content in the nanocomposites was determined by atomic emission spectroscopy by using a spectrometer (ICPE-9000, Shimadzu).

Nanocomposites based on kaolin were characterized by the results of the studies by means of a Hitachi H-800 transmission electron microscope (TEM) using electron diffraction in the selected area. The size of the particles was determined by analyzing dark-field images using a linear measurement program and selecting more than 40 objects for each sample. Nanocomposites were characterized by scanning electron microscopy (MIRA3 LMU, TESCAN) with an Oxford X-MAX $80 \mathrm{~mm}^{2}$ energy-dispersive spectroscopic chemical analysis system with an instrument uncertainty of $\pm 1 \%$. A Thermo Nicolet Nexus FT-IR spectrometer was used to record the IR spectra of kaolin and nanocomposites in the range of $4000-400 \mathrm{~cm}^{-1}$ in diffuse reflection mode with a measurement uncertainty of $\pm 1.8 \mathrm{~cm}^{-1}$ at room temperature. The UV spectra of kaolin and nanocomposites were recorded by means of a UV-VIS-NIR spectrophotometer UV-3600, Shimmadzu in the diffuse reflection mode in the range of $220-330 \mathrm{~nm}$ with an instrument uncertainty of $\pm 1 \mathrm{~nm}$. Electronographic analysis of nanocomposites was performed using a Hitachi H800 transmission electron microscope (TEM). X-ray analysis was conducted by means of a DRON-4-07 diffractometer.

The enzyme activity of the test materials and the effective activation energy of the reaction were determined in a model reaction of the decomposition of hydrogen peroxide. A volumetric method was used to establish the kinetics of the decomposition of hydrogen peroxide. The initial concentration of hydrogen peroxide in solutions was determined by permanganometric titration. The experiment was conducted for 30 min with a constant stirring of the reaction mixture having a total volume of $25 \mathrm{~mL}$. The volume of oxygen released was fixed with a precision of $0.01 \mathrm{~mL}$. The numerical determination and comparison of the catalase activity of nanomaterials and the enzyme catalase were made in accordance with the concepts of the enzyme reactions using the Michaelis constant $\left(\mathrm{K}_{\mathrm{m}}, \mathrm{mM}\right)$. The maximum reaction rate was determined from the kinetic data of the decomposition of substrate solutions with a concentration of $1-10 \%$ in the $\mathrm{pH}$ range of 8.5 to 10.5 (borate buffer) by the optimum catalyst weight. The Michaelis constant was 


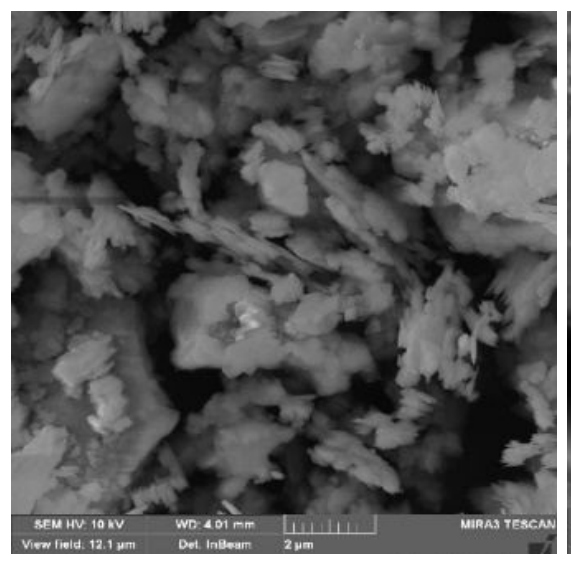

a

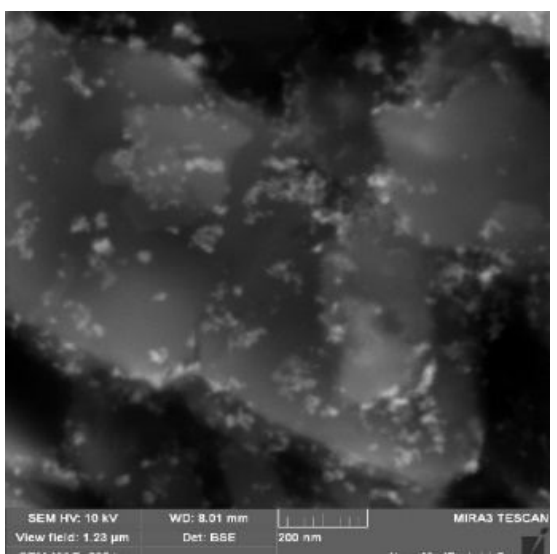

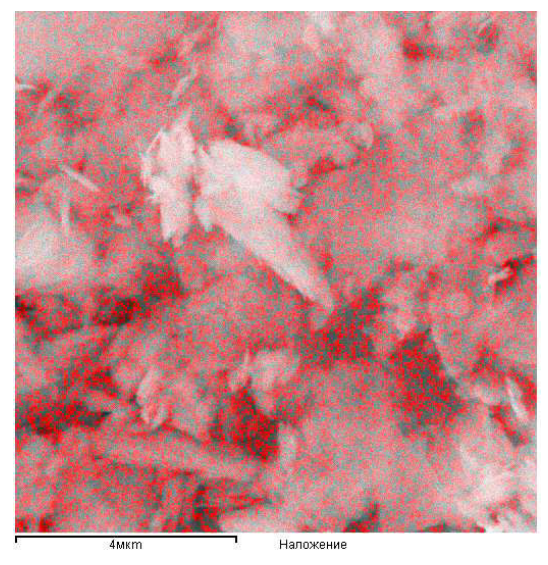

Fig. 1. SEM images of kaolin (a) and K-9Ce nanocomposite (b). (c) - the distribution of $\mathrm{CeO}_{2}$ in the material

determined from the graph of the maximum reaction rate versus concentration in the double reciprocal Lineweaver-Burk coordinates. The reliability of the approximation of the linearization of the experimental data in almost all cases exceeds 0.95. To facilitate the interpretation of the obtained experimental data, the affinity constant $\left(\mathrm{K}_{\mathrm{af}}, \mathrm{mM}^{-1}\right.$ reverse to the Michaelis constant) was used. The activation energy of the reaction was determined based on the

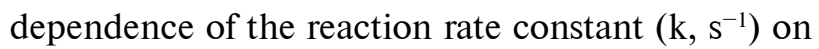
the reciprocal temperature. To determine the activation energy of the reaction of the decomposition reaction of hydrogen peroxide, the experiments were carried out at the temperatures of $20,25,30,35$, $40^{\circ} \mathrm{C}(\mathrm{pH} 10.0)$.

\section{Results and discussion}

The dispersion and particle distribution of the modifier in the nanocomposite determine its catalytic and biological activities. Electron microscopic examinations of the pristine kaolin revealed the compliance of its structure and morphology with the data of material certificate. SEM images showed that the size of kaolin particles in the samples varied from hundreds of nanometers to tens of micrometers (Fig. 1).

After the modification, nanoscale particles are observed in the nanocomposite images. Analysis of SEM and TEM images of identical samples allows us to claim that these are particles of nanoceria. The study of the structure and morphology of kaolin nanocomposites with nanoceria deposited on its surface revealed the presence of nanosized particles, the number of which increases with increasing content of nanoceria in nanocomposites. The nanoparticles are evenly distributed on the surface of the kaolin particles, and the uniformity of its deposition remains with increasing nanoceria content. Figure 2 shows the TEM images of the edges of
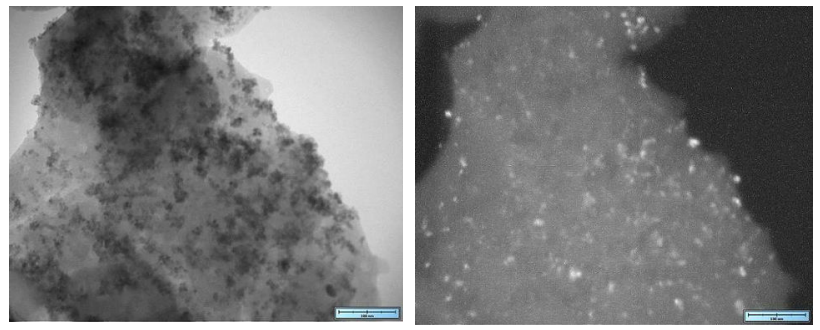

Fig. 2. TEM images in light and dark fields of nanocomposite K-9Ce

particles of a $\mathrm{K}-9 \mathrm{Ce}$ nanocomposite in light and dark fields.

The analysis of images of nanocomposites with different content of nanoceria showed that an increase in the concentration of the modifier during the process of synthesis leads to the formation of larger decorator particles (Table). The dependence of the average diameter of the nanosized cerium dioxide particles on its content is linear (Fig. 3).

Electron diffraction study of particles revealed reflections with d (hkl)=3.12 $\AA(111), 2.7 \AA(200)$,

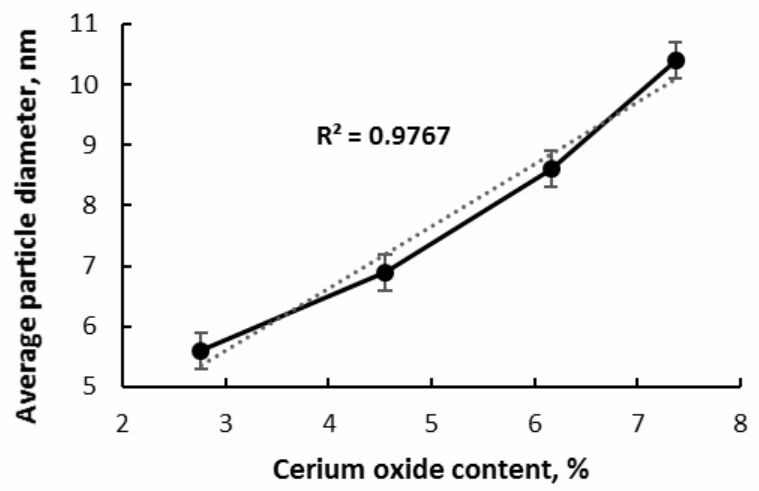

Fig. 3. The dependence of the particle size of nanoceria on its content in the nanocomposites according to electron microscopy 


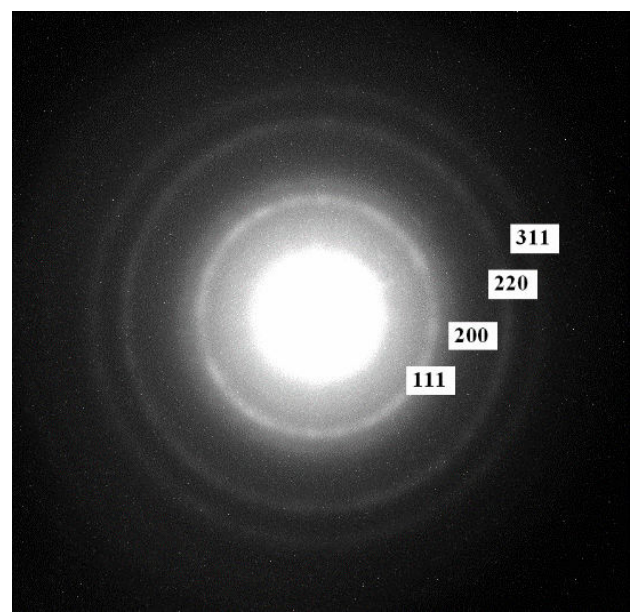

Fig. 4. Electronogram of particles in the nanocomposite is $\mathrm{d}(\mathrm{hkl})=3.12(111), 2.7(200), 1.89(220)$ and $1.64 \AA(311)$

$1.89 \AA$ (220), and $1.64 \AA$ (311), which indicates the cubic structure of nanosized cerium dioxide (Fig. 4). The significant blurring of modifier signals can be explained by the influence of the nanosized crystallites and the low crystallinity of nanoceria.

The synthesis parameters of the materials were calculated to obtain nanocomposites with modifier content of 3,5, 7 and 9 weight percent. According to the results of atomic emission spectrometry (Table), the content of $\mathrm{CeO}_{2}$ in the synthesized samples varies within the range of $2.76 \%$ to $7.37 \%$. This is due to the leaching of $\mathrm{CeO}_{2}$ at the filtration stage.

In addition to the size of nanocrystallites, the catalytic activity of nanoceria is determined by the presence of $\mathrm{Ce}^{3+}$ atoms on the surface or by its defect, which is characterized by the ratio $\mathrm{Ce}^{4+} / \mathrm{Ce}^{3+}[6]$. This was determined from the UV spectra of diffuse reflection of kaolin and synthesized ceriumcontaining nanocomposites (Fig. 5). In the spectrum of unmodified kaolin, a number of maxima (the most intense at $251.5 \mathrm{~nm}$ ) related to impurities of iron, titanium and others in aluminosilicate were detected. The content of these ions was determined by energy dispersion analysis. The modification of kaolin caused

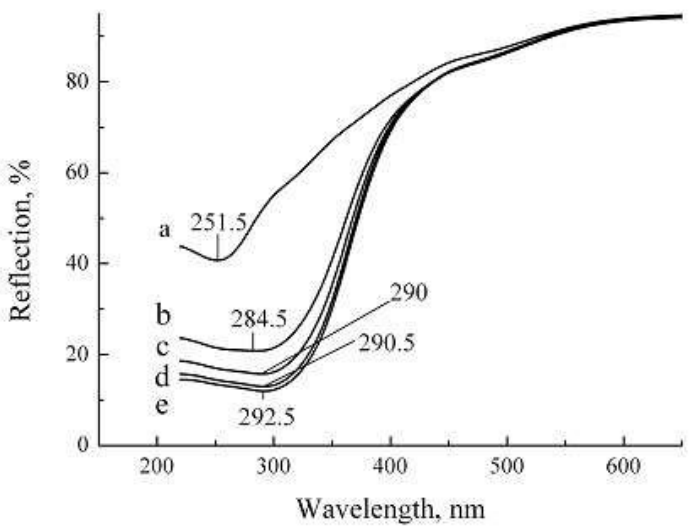

Fig. 5. UV-Vis spectra of kaolin (a) and nanocomposites $\mathrm{K}-3 \mathrm{Ce}(\mathrm{b}), \mathrm{K}-5 \mathrm{Ce}(\mathrm{c}), \mathrm{K}-7 \mathrm{Ce}(\mathrm{d}), \mathrm{K}-9 \mathrm{Ce}(\mathrm{e})$. The wavelengths corresponding to the peaks are indicated in Figure

the appearance of a signal from nanoceria in the spectra.

Maximum signals at $284.5 \mathrm{~nm}$ (K-3Ce), $290 \mathrm{~nm}$ (K-5Ce), $290.5 \mathrm{~nm}(\mathrm{~K}-7 \mathrm{Ce})$ and $292.5 \mathrm{~nm}$ (K-9Ce) shifted to a long-wavelength region with increasing the content of nanoceria, which confirmed the observations reported elsewhere [7].

The $\mathrm{Ce}^{4+} / \mathrm{Ce}^{3+}$ ratio was defined as the ratio of the integral signal intensities (Fig. 6,a). Mathematical processing of UV-Vis spectra of nanocomposites allowed decomposing the peaks of cerium oxide into two components, corresponding to cerium in different valence states: $\mathrm{Ce}^{3+}$ and $\mathrm{Ce}^{4+}$. An increase in the content of cerium oxide and, accordingly, in nanoparticle diameter results in an increase in the relative content of $\mathrm{Ce}^{4+}$ and a decrease in the relative content of $\mathrm{Ce}^{3+}$ (Table). The $\mathrm{Ce}^{4+}$ and $\mathrm{Ce}^{3+}$ ions correspond to the peaks with maxima at $198-219 \mathrm{~nm}$ and $311-323 \mathrm{~nm}$, respectively. This analysis of $\mathrm{UV}$-Vis spectra is not quantitative; it only allows us to estimate the relative content of multivalent state of cerium in nanoparticles.

When the content of $\mathrm{CeO}_{2}$ in nanocomposites increases, a shift of the peak maximum to the long-

Catalysts characteristics and activation energy of the reaction of hydrogen peroxide decomposition by them

\begin{tabular}{c|c|c|c|c}
\hline Material & $\mathrm{CeO}_{2}$ content, \% & $\begin{array}{c}\text { Average particle } \\
\text { diameter, } \mathrm{nm}\end{array}$ & $\begin{array}{c}\mathrm{I}_{\mathrm{UvsCe}}^{4+} / \mathrm{I}_{\mathrm{UvS} \mathrm{Ce}}^{3+} \text { in UV-spectra } \\
\text { of nanocomposite }\end{array}$ & $\mathrm{E}_{\mathrm{a}}, \mathrm{kJ} / \mathrm{mol}$ \\
\hline $\mathrm{Kaolin}$ & - & - & - & 221 \\
\hline $\mathrm{K}-3 \mathrm{Ce}$ & $2.76 \pm 0.01$ & 5.6 & 0.98 & 195 \\
\hline $\mathrm{K}-5 \mathrm{Ce}$ & $4.55 \pm 0.02$ & 6.9 & 1.33 & 172 \\
\hline $\mathrm{K}-7 \mathrm{Ce}$ & $6.16 \pm 0.02$ & 8.6 & 2.11 & 149 \\
\hline $\mathrm{K}-9 \mathrm{Ce}$ & $7.37 \pm 0.04$ & 10.4 & 2.88 & 139 \\
\hline $\mathrm{CeO}_{2}$ (nanosized) & 100.00 & 31.0 & - & 125 \\
\hline
\end{tabular}




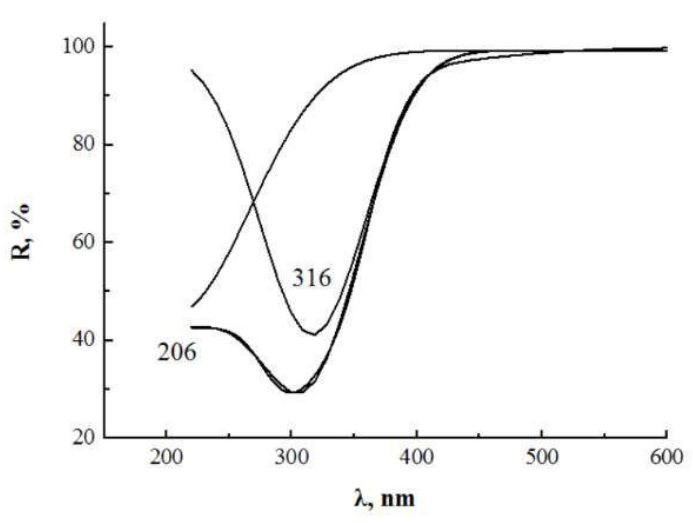

a

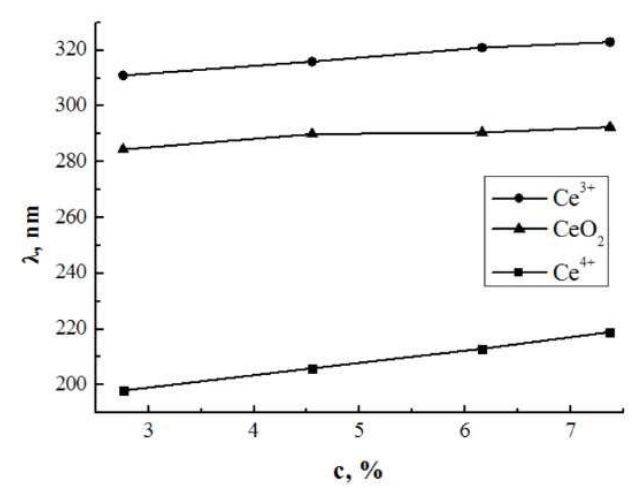

b

Fig. 6. (a) - UV-Vis spectrum of cerium(IV) oxide in K-5Ce nanocomposites and its decomposition into components,

(b) - dependence of the peaks maximum position in the $\mathrm{UV}$-Vis spectra of $\mathrm{Ce}^{3+}, \mathrm{Ce}^{4+}$ and $\mathrm{CeO}_{2}$ on the content of cerium(IV) oxide in nanocomposites

wavelength region (bathochromic effect) is observed in the UV-Vis spectra. The more intense shift is ascribed to $\mathrm{Ce}^{4+}$, which confirms an increase in $\mathrm{Ce}^{4+}$ relative content in the nanocomposite with increasing the content of nanoceria (Fig. 6,b). When the content of the decorator in the nanocomposite increases, the size of $\mathrm{CeO}_{2}$ nanocrystallites increases (Fig. 3), while their surface decreases, the ratio of $\mathrm{I}_{\mathrm{UvS}} \mathrm{Ce}^{4+} / \mathrm{I}_{\mathrm{UvS}} \mathrm{Ce}^{3+}$ increases, and the quantity of surface defects decreases (Table).

The IR spectra of nanocomposites are not significantly different from those of kaolin (Fig. 7). The absorption bands of the hydroxyl groups and adsorbed water are observed in the spectra at 3750$3600 \mathrm{~cm}^{-1}$ and $3550-3400 \mathrm{~cm}^{-1}$, respectively. The $\mathrm{Al}-\mathrm{O}$ and $\mathrm{Si}-\mathrm{O}$ bond bands of the kaolin framework appear below $1200 \mathrm{~cm}^{-1}$. It is obvious that we could not detect chemical interaction between the modifier and the matrix (formation of a chemical bond), which would affects the vibrational spectra of the modified

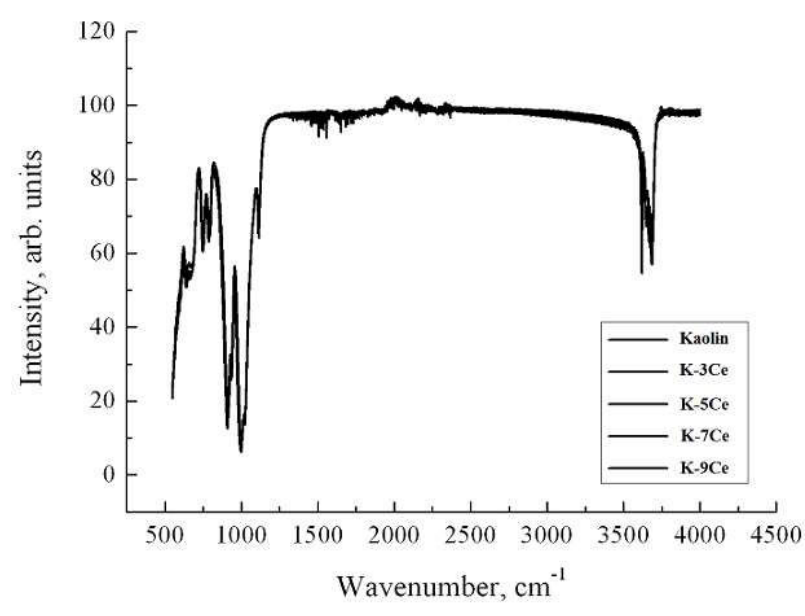

Fig. 7. IR spectra of nanocomposites and pristine kaolin kaolin.

Since the $4 \mathrm{f}$ and $5 \mathrm{~d}$ orbitals in the cerium atom are partially filled and very little energy is necessary to change the relative occupancy of these electronic levels, cerium has two stable valence states $(+4$ and $+3)$ and forms two oxides $\left(\mathrm{CeO}_{2}\right.$ and $\left.\mathrm{Ce}_{2} \mathrm{O}_{3}\right)$. The transition from an ion $\mathrm{Ce}^{4+}$ with a smaller ionic radius $(0.92 \AA)$ to an ion $\mathrm{Ce}^{3+}$ with a larger radius $(1.034 \AA)$ leads to the loss of oxygen and the formation of oxygen vacancies, which are considerable defects in the lattice structure [8].

To balance the charge after the release of oxygen, two $\mathrm{Ce}^{4+}$ atoms are restored to $\mathrm{Ce}^{3+}$ state with the formation of an oxygen vacancy:

$$
\mathrm{CeO}_{2} \rightarrow \mathrm{CeO}_{2-\mathrm{x}}+\frac{1}{2} \mathrm{xO}_{2}(\mathrm{~g}),
$$

where $0 \leq x \leq 0.5$.

The higher concentration of oxygen vacancies provides greater mobility of oxygen atoms in the crystal. This promotes redox reactions on its surface and determines a high catalytic activity of the material, thereby making nanoceria effectively bind the free radicals, which include reactive oxygen species. To limit the concentration of ROS, in particular superoxide and peroxide compounds, the cells produce superoxide dismutase and catalase enzymes. The ability of cerium to switch between the oxidation states and the coexistence of $\mathrm{Ce}^{3+}$ and $\mathrm{Ce}^{4+}$ ions on its surface allows nanoceria to exhibit catalase and superoxide dismutase catalytic enzymatic activity. The mechanism of decomposition of hydrogen peroxide by heavy metal ions was proposed by Haber and Weiss, supplemented by Bard and associated with the transition of electrons between surface ions and solid atoms and liquid phase

Kaolin/cerium oxide nanocomposites: properties and activity in hydrogen peroxide decomposition reaction 
components $[9,10]$ :

$$
\begin{gathered}
\mathrm{Ce}^{3+}+\mathrm{H}_{2} \mathrm{O}_{2} \rightarrow \mathrm{Ce}^{4+}+\mathrm{OH}^{-}+{ }^{\bullet} \mathrm{OH} \\
\mathrm{H}_{2} \mathrm{O}_{2}+{ }^{\bullet} \mathrm{OH} \rightarrow \mathrm{H}_{2} \mathrm{O}+\mathrm{HO}_{2}^{\cdot} \\
\mathrm{HO}_{2}^{\bullet} \rightarrow \mathrm{H}^{+}+\mathrm{O}_{2}^{-} \\
\mathrm{Ce}^{4+}+\mathrm{O}_{2}^{-} \rightarrow \mathrm{Ce}^{3+}+\mathrm{O}_{2} \\
\mathrm{Ce}^{3+}+\mathrm{HO}_{2}^{\cdot} \rightarrow \mathrm{Ce}^{4+}+\mathrm{HO}_{2}^{-} \\
\mathrm{Ce}^{4+}+\mathrm{HO}_{2}^{-} \rightarrow \mathrm{Ce}^{3+}+\mathrm{HO}_{2}^{\bullet}
\end{gathered}
$$

During the recovery of superoxide by nanoceria, hydrogen peroxide is formed and the $\mathrm{Ce}^{3+}$ ion is oxidized to $\mathrm{Ce}^{4+}$. The formed $\mathrm{Ce}^{4+}$ ion is able to react with the $\mathrm{H}_{2} \mathrm{O}_{2}$ molecule, while it is reduced to the $\mathrm{Ce}^{3+}$ ion and $\mathrm{H}_{2} \mathrm{O}_{2}$ is oxidized to $\mathrm{O}_{2}[11]$ :

$$
\begin{gathered}
2 \mathrm{Ce}^{3+}+\mathrm{H}_{2} \mathrm{O}_{2}+2 \mathrm{H}^{+} \rightarrow 2 \mathrm{H}_{2} \mathrm{O}+2 \mathrm{Ce}^{4+} \\
\mathrm{Ce}^{4+}+\mathrm{H}_{2} \mathrm{O}_{2}+\mathrm{e}^{-} \rightarrow \mathrm{Ce}^{3+}+\mathrm{H}^{+}+\mathrm{HOO}^{\bullet} \\
\mathrm{Ce}^{4+}+\mathrm{HOO}^{\bullet}+\mathrm{e}^{-} \rightarrow \mathrm{Ce}^{3+}+\mathrm{O}_{2}+\mathrm{H}^{+} \\
2 \mathrm{Ce}^{4+}+\mathrm{H}_{2} \mathrm{O}_{2} \rightarrow 2 \mathrm{Ce}^{3+}+\mathrm{O}_{2}+2 \mathrm{H}^{+}
\end{gathered}
$$

A model of the mechanism of enzyme-like activity of nano-sized $\mathrm{CeO}_{2}$ was proposed. It clearly demonstrates the ability of a material to decompose hydrogen peroxide by two different mechanisms, one of which is similar to the action of the superoxide dismutase enzyme, and the other resembles the action of the enzyme catalase. The combination of these two sequential redox reactions, namely the conversion of superoxide to peroxide and peroxide to $\mathrm{O}_{2}$, makes nanoceria an ideal antioxidant, because it can cyclically and infinitely long (theoretically) absorb two active forms of oxygen.

It was reported [12] that cerium preparations exhibit enzymatic (catalase and superoxide dismutase) activity. Therefore, we have numerically determined and compared the catalytic capacity of kaolin, synthesized nanocomposites with different $\mathrm{CeO}_{2}$ content (samples $\mathrm{K}-3 \mathrm{Ce}, \mathrm{K}-5 \mathrm{Ce}, \mathrm{K}-7 \mathrm{Ce}$ and $\mathrm{K}-9 \mathrm{Ce}$ ), a commercial preparation of pure nanoceria and catalase enzyme in a model reaction of hydrogen peroxide decomposition [13] in the $\mathrm{pH}$ range of 8.5 to 10.5 from the standpoint of the formal kinetics of enzymatic reactions. For this purpose, the linear interval of the maximum rate of hydrogen peroxide decomposition for the catalyst sample weights lying in the range of $0.000-0.035 \mathrm{~g}$ was experimentally determined and the catalyst sample with the weight of $0.025 \mathrm{~g}$ was selected for further study. The activity of the investigated nanocomposites was compared with the previously established data for nanosized cerium dioxide and the catalase enzyme [13].

It was shown that pure nanoceria is the most active among the studied catalysts in the selected $\mathrm{pH}$ range. Its affinity constant for $\mathrm{pH} 9.5$ is $0.0500 \mathrm{mM}^{-1}$, which is almost 30 times higher than that for the catalase enzyme. Under these conditions, i.e. beyond the optimum $\mathrm{pH}$, the activity of the catalyst is low.

The activity of kaolin (a carrier of the decorator in the synthesized nanocomposites) was found to be low, it was decreased with increasing $\mathrm{pH}$ and comparable in magnitude with the activity of the enzyme. The presence of a modifier in the composition of the nanocomposite $(2.76 \%)$ caused an almost twofold increase in the activity of the nanocomposite as compared with the carrier.

An extreme dependence of the activity of deposited catalysts on the $\mathrm{pH}$ with a maximum at pH 10.0 was established (Fig. 8). Vlasova et al. [14] reported that the catalytic activity of nanosized $\mathrm{CeO}_{2}$ with respect to the decomposition of $\mathrm{H}_{2} \mathrm{O}_{2}$ increases with changing $\mathrm{pH}$ of the medium from 3 to 9 . An increase in catalytic activity in the $\mathrm{pH}$ range of 8.0 to 10.0 can be associated with an increase in the number of $\equiv \mathrm{Ce}-\mathrm{O}^{-}$groups on the surface of nanoceria involved in the oxidation-reduction reactions of hydrogen peroxide interaction with $\mathrm{Ce}^{4+}$ ions and $\mathrm{Ce}^{3+}$ by Garber and Weiss. The number of protonated $\left(\equiv \mathrm{CeOH}_{2}^{+}\right)$and deprotonated $\left(\equiv \mathrm{CeO}^{-}\right)$ groups on the surface of nanoceria was calculated based on the Stern model of complex formation taking into account the protonation, dissociation, and formation of outer-sphere complexes with electrolyte ions, which are $210 \mu \mathrm{mol} / \mathrm{g}$ and $125 \mu \mathrm{mol} / \mathrm{g}$ for $\mathrm{pH} 2$ and $\mathrm{pH} 9$, respectively [14]. A further increase in $\mathrm{pH}$ of the medium leads to a decrease in the catalytic activity of cerium-containing nanomaterials, which is caused by the formation of low-bonded $\mathrm{Ce}^{3+}$ compounds on the surface of nanoceria. Thus, the solubility constant of $\mathrm{Ce}(\mathrm{OH})_{3}$ at $25^{\circ} \mathrm{C}$ is $6.3 \cdot 10^{-24}$ [15].

It was found that the catalytic activity of cerium-containing materials $\left(\mathrm{K}_{\mathrm{af}}\right)$ is directly proportional to the content of nanoceria in the composite (Fig. 9).

The conversion of the catalytic capacity of nanocomposites to $100 \%$ of the decorator content in them (Fig. 10,a) allows us to analyze the factors that determine the activity of nanosized $\mathrm{CeO}_{2}$. 


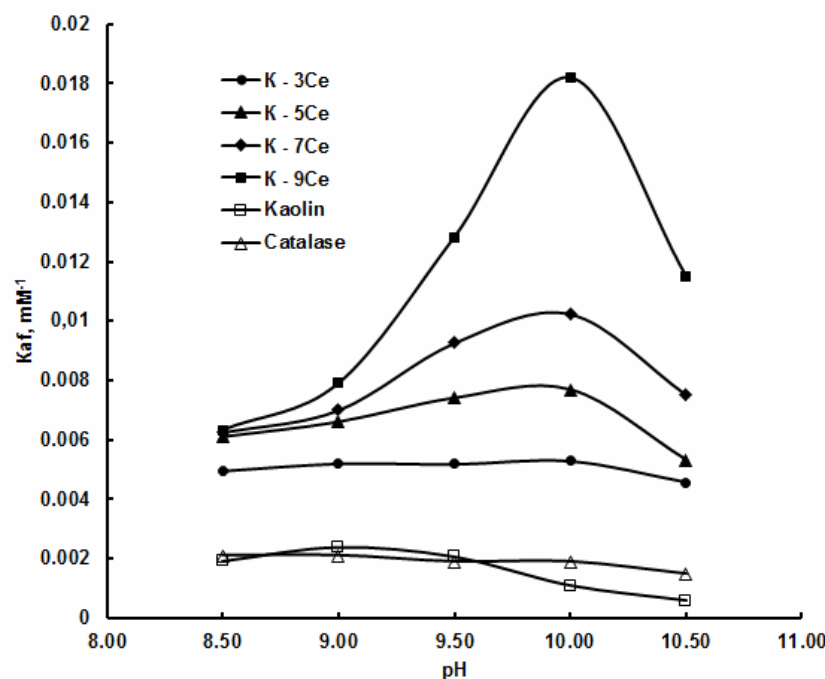

Fig. 8. Dependence of the catalytic activity of materials $\left(\mathrm{K}_{\mathrm{af}}\right)$ on the $\mathrm{pH}$ in the reaction of hydrogen peroxide decomposition

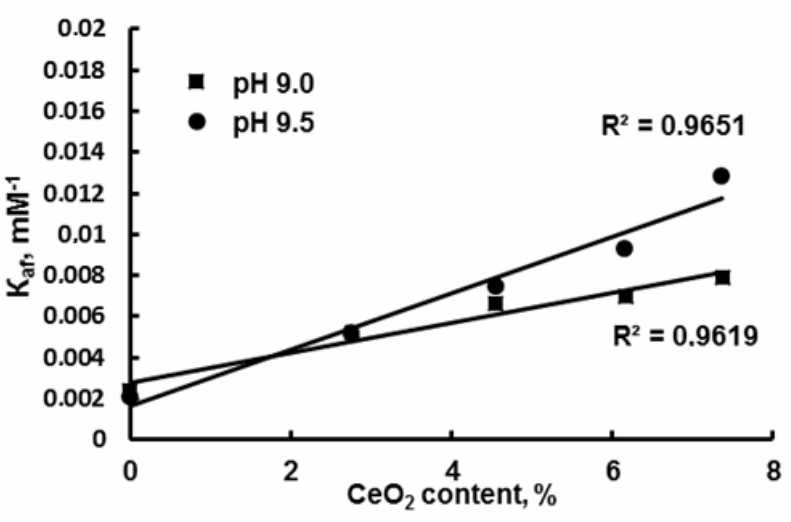

Fig. 9. Linear dependences of nanomaterial activity on the content of $\mathrm{CeO}_{2}$

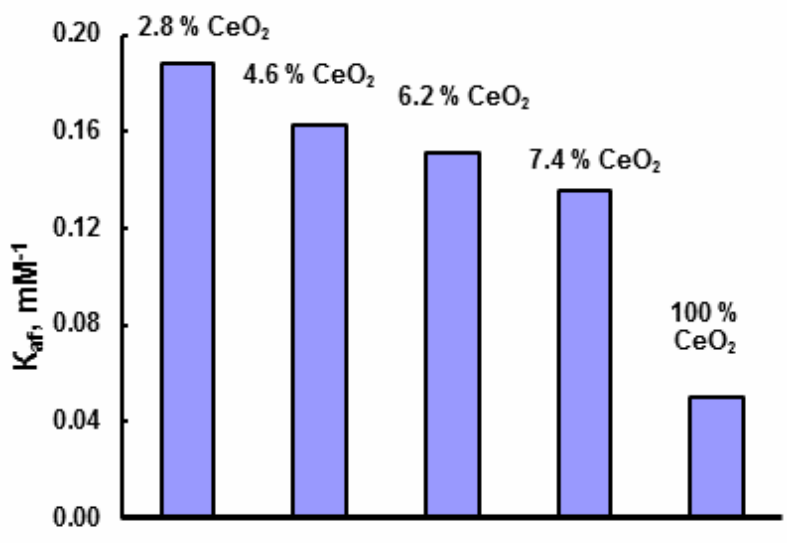

Fig. 10. The activity of nanocomposites at $\mathrm{pH} 9.5$ in terms of $100 \%$ content of cerium oxide (a), and its dependence on the ratio of $\mathrm{Ce}^{4+} / \mathrm{Ce}^{3+}$
It was found that the highest catalytic ability in terms of $100 \%$ content of cerium oxide was reached for the material $\mathrm{K}-3 \mathrm{Ce}$ with a modifier content of $2.8 \%, 5.6 \mathrm{~nm}$ nanocrystallites size and $\mathrm{Ce}^{4+} / \mathrm{Ce}^{3+}$ ratio of 0.98 . The activity of this sample is 3.8 times higher than that of commercial nanosized $\mathrm{CeO}_{2}$ with $31 \mathrm{~nm}$ nanocrystallites and 1.2-1.4 times higher than the remaining nanocomposites. The activity of nanosized $\mathrm{CeO}_{2}$ in nanocomposites decreases with an increase in both the size of the nanocrystallites and the $\mathrm{Ce}^{4+} / \mathrm{Ce}^{3+}$ ratio (Fig. 10,b). As the size of the modifier particles decreases, their surface area increases and, accordingly, the relative content of $\mathrm{Ce}^{3+}$ ions (defects) in it increases, the presence of which being associated with the catalytic activity of nanoceria.

The activation energies $\left(E_{a}\right)$ of the reaction of hydrogen peroxide decomposition by the nanocomposites and pristine kaolin in the temperature range of $20-40^{\circ} \mathrm{C}$ at $\mathrm{pH} 10$ were determined.

It was shown that the activation energy for pristine kaolin is $221 \mathrm{~kJ} / \mathrm{mol}$. The activation energy changed from $195 \mathrm{~kJ} / \mathrm{mol}$ for the material with the lowest modifier content to $139 \mathrm{~kJ} / \mathrm{mol}$ for the nanocomposite with the highest amount of a modifier (Table). It was found that the activation energy of the decomposition of hydrogen peroxide decreased with increasing the content of nanoceria (\%) and the ratio of $\mathrm{I}_{\mathrm{UVS} \mathrm{Ce}}{ }^{4+} / \mathrm{I}_{\mathrm{UVS} \mathrm{Ce}}{ }^{3+}$, which is a measure of the surface defect of nanocrystals of $\mathrm{CeO}_{2}$ (Fig. 11).

Contrary to expectation, an increase in the size of crystallites of nanosized $\mathrm{CeO}_{2}$ leads to a decrease in the activation energy. It can be concluded that the catalytic activity of cerium-containing nanocomposites and the reduction of the activation energy of the $\mathrm{H}_{2} \mathrm{O}_{2}$ decomposition reaction are determined by the absolute content of the decorator

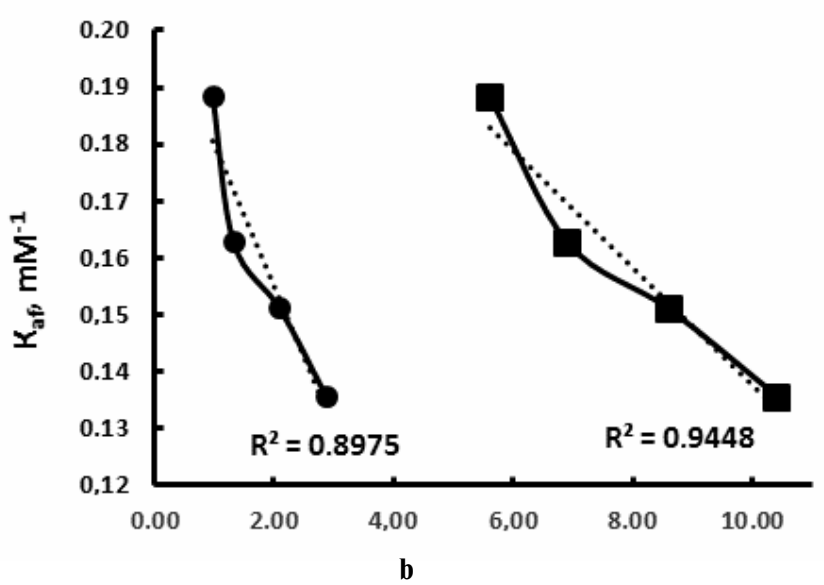

Kaolin/cerium oxide nanocomposites: properties and activity in hydrogen peroxide decomposition reaction 


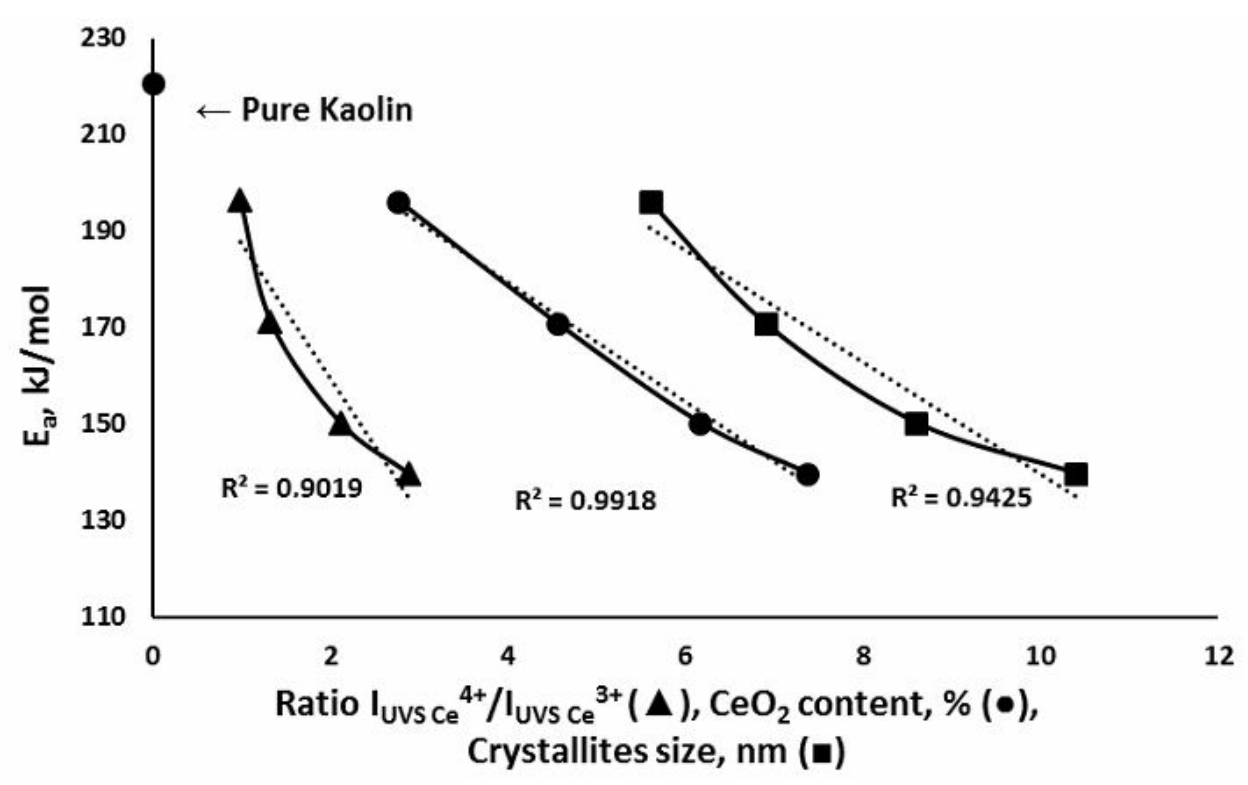

Fig. 11. Dependence of the activation energy of the decomposition reaction of hydrogen peroxide by nanocomposites of kaolincerium oxide on the content of $\mathrm{CeO}_{2}(\bullet)$, crystallite size $(\boldsymbol{\square})$ and the ratio of $\mathrm{I}_{\mathrm{UvS} \mathrm{Ce}^{4+}} / \mathrm{I}_{\mathrm{Uvs} \mathrm{Ce}}{ }^{3+}(\boldsymbol{\Delta})$

or by the amount of $\mathrm{Ce}^{3+}$ ions in them. The efficiency of cerium-containing catalysts can be increased if it is possible either to synthesize nanocomposites with high weight content of a decorator which nanoparticle size should be small or increase the specific content of $\mathrm{Ce}^{3+}$ ions on the surface of nanosized $\mathrm{CeO}_{2}$.

\section{Conclusions}

A number of composite kaolin-cerium oxide based materials were synthesized via deposition reaction using aqueous cerium nitrate solutions without any stabilizers at room temperature. By the methods of physical and chemical analysis, the characteristics of the studied materials were determined. According to atomic emission spectrometry, the amount of applied cerium oxide in nanomaterial was in the range of $2.76 \%$ to $7.37 \%$. The nanoceria particle size determined from the SEM images was $5.6-10.4 \mathrm{~nm}$ and proportional to its content in the nanocomposite. The TEM images showed the morphology of the modifier particles in the synthesized materials. IR spectroscopy confirmed that chemical interaction between the modifier and the matrix (i.e. formation of a chemical bond) was not detected. The diffuse reflection UV spectroscopy evaluated the $\mathrm{I}_{\mathrm{UvS} \mathrm{Ce}}{ }^{4+} / \mathrm{I}_{\mathrm{UvS} \mathrm{Ce}}{ }^{3+}$ ratio as a measure of the number of surface defects in nanocomposites.

The catalytic activity of the synthesized materials and kaolin in the model reaction of hydrogen peroxide decomposition in the $\mathrm{pH}$ range of $8.5-10.5$ was investigated by calculating the affinity constant from kinetic data within the range of enzymatic reactions. The catalytic activity was compared with that of the catalase enzyme and commercial nanosized $\mathrm{CeO}_{2}$. It was shown that the dependence of the activity of the samples on $\mathrm{pH}$ exhibited a maximum at $\mathrm{pH} 10.0$.

The activation energy of the reaction of hydrogen peroxide decomposition by nanocomposites and kaolin at $\mathrm{pH} 10.0$ in the temperature range of $20-40^{\circ} \mathrm{C}$ was established. It was found that the catalytic activity of nanocomposites was increased at a constant $\mathrm{pH}$. The activation energy was decreased when the content of a decorator increased. The analysis of the factors that determine the activity of nanoceria in the composition of nanocomposites showed that an increase both in the dispersion of nanocrystallites and in the relative content of $\mathrm{Ce}^{3+}$ ions leads to an improvement in the catalytic ability of nanomaterials.

\section{REFERENCES}

1. Exploring the properties and applications of nanoceria: is there still plenty of room at the bottom? / Reed K., Cormack A., Kulkarni A., Mayton M., Sayle D., Klaessig F., Stadler B. // Environ. Sci. Nano. - 2014. - Vol.1. - No. 5. - P.390-405.

2. Turkan I. ROS and RNS: key signaling molecules in plants // J. Exp. Bot. - 2018. - Vol.69. - No. 14. - P.33133315.

3. The enzyme-like catalytic activity of cerium oxide nanoparticles and its dependency on $\mathrm{Ce}^{3+}$ surface area concentration / Baldim V., Bedioui F., Mignet N., Margaill I., 
Berret J.-F. // Nanoscale. - 2018. - Vol.10. - No. 15. - P.69716980.

4. Nanoceria exhibit redox state-dependent catalase mimetic activity / Pirmohamed T., Dowding J.M., Singh S., Wasserman B., Heckert E., Karakoti A.S., King J.E.S., Seal S., Self W.T. // Chem. Commun. - 2010. - Vol.46. - No. 16. - P.2736-2738.

5. pH-responsive morphology-controlled redox behavior and cellular uptake of nanoceria in fibrosarcoma / Mehmood R., Ariotti N., Yang J.L., Koshy P., Sorrell C.C. // ACS Biomater. Sci. Eng. - 2018. - Vol. 4. - No. 3. - P.1064-1072.

6. Size- and defect-controlled anti-oxidant enzyme mimetic and radical scavenging properties of cerium oxide nanoparticles / Vinothkumar G., Arunkumar P., Mahesh A., Dhayalan A., Suresh Babu K. // New J. Chem. - 2018. - Vol.42. - No. 23. - P.1881018823.

7. Lin K.S., Chowdhury S. Synthesis, characterization, and application of 1-D cerium oxide nanomaterials: a review // Int. J. Mol. Sci. - 2010. - Vol.11. - No. 9. - P.3226-3251.

8. Superoxide dismutase mimetic properties exhibited by vacancy engineered ceria nanoparticles / Korsvik C., Patil S., Seal S., Self W.T. // Chem. Commun. - 2007. - P.1056-1058.

9. Nagiev T.M. Khimicheskoe sopryazhenie: sopryazhennye reaktsii okisleniya perekis'yu vodoroda. - M.: Nauka, 1989. $216 \mathrm{p}$.

10. Xu L.J., Wang J.L. Magnetic nanoscaled $\mathrm{Fe}_{3} \mathrm{O}_{4} / \mathrm{CeO}_{2}$ composite as an efficient Fenton-like heterogeneous catalyst for degradation of 4-chlorophenol // Environ. Sci. Technol. - 2012. - Vol.46. - No. 18. - P.10145-10153.

11. Ceria nanoparticles as enzyme mimetics / Wang G., Zhang J., He X., Zhang Z., Zhao Y. // Chin. J. Chem. - 2017. - Vol.35. - No. 6. - P.791-800.

12. Morphology- and $\mathrm{pH}$-dependent peroxidase mimetic activity of nanoceria / Wei X., Li X., Feng Y., Yang S. // RSC Adv. - 2018. - Vol.8. - No. 21. - P.11764-11770.

13. Catalytic activity of cerium-containing materials in reaction of hydrogen peroxide decomposition / Dmytrenko T.Yu., Kulyk K.S., Voitko K.V., Bakalinska O.N., Borysenko N.V., Kartel M.T. // Khimiya, Fizyka ta Tekhnologiya Poverkhni. 2014. - Vol.5. - No. 3. - P.317-324.

14. Vlasova N.N., Golovkova L.P., Stukalina N.G. Adsorption of organic acids on a cerium dioxide surface // Colloid J. - 2015. Vol.77. - P.418-424.

15. Zhou X.D., Huebner W., Anderson H.U. Processing of nanometer-scale $\mathrm{CeO}_{2}$ particles // Chem. Mater. - 2003. - Vol.15. - No. 2. - P.378-382.

\section{НАНОКОМПОЗИТИ КАОЛІН/ОКСИД ЦЕРІЮ: ВЛАСТИВОСТІ ТА АКТИВНІСТЬ У РЕАКЦІЇ РОЗКЛАДАННЯ ПЕРОКСИДУ ВОДНЮ}

\section{А.М. Гринько, А.В. Бричка, О.М. Бакалінська, О.I. Оранська, М.Т. Картель}

Методом осадження з водних розчинів иерій нітрату, без стабілізаторів, при кімнатній температурі, синтезовано та охарактеризовано властивості низки наноматеріалів на основі каоліну, декорованих $\mathrm{CeO}_{2}$. Кількість нанесеного церій оксиду в наноматеріалах становить 2,76-7,37\%, а їх розмір варіюється від 5,6 до 10,4 нм. Рентгеноструктурний аналіз зразків показав, що иерій діоксид має кубічну структуру. За IЧ спектрами вихідного каоліну та нанокомпозитів не можна виявити хімічну взаємодію між модифікатором і матрицею (утворення хімічного зв'язку). Співвідношення $\mathrm{Ce}^{4+} / \mathrm{Ce}^{3+}$ в нанокомпозитах, оцінене за УФ-спектрами дифузного відбиття варіюється у межсах 0,98-2,88. Розрахунком константи аффінності із кінетичних даних, у межсах уявлень про перебіг ензиматичних реакцій, було визначено каталітичну активність синтезованих матеріалів та каоліну у модельній реакції розкладання пероксиду водню у інтервалі рН 8,5-10,5 та порівняно із ферментом каталаза $і$ комериійним нанорозмірним $\mathrm{CeO}_{2}$. Показано, що залежність активності зразків від рН екстремальна з максимумом при рН 10,0. Визначено енергію активації реакції розкладання пероксиду водню досліджуваними нанокомпозитами та каоліном в діапазоні температур $20-40^{\circ} \mathrm{C}$ при рН 10,0. Встановлено що при сталому рН середовища каталітична активність нанокомпозитів збільшується, а енергія активації зменшується при збільшенні вмісту декоратора. Аналіз факторів, що визначають активність нанорозмірного церій оксиду у складі нанокомпозитів, показують, що збільшення дисперсності нанокристалітів та відносного вмісту іонів Се $\mathrm{C}^{3+}$ на їх поверхні приводить до покращення каталітичної здатності наноматеріалів.

Ключові слова: нанорозмірний церій оксид, каолін, нанокомпозити, каталітична активність, енергія активації, розкладання пероксиду водню. 


\section{KAOLIN/CERIUM OXIDE NANOCOMPOSITES: PROPERTIES AND ACTIVITY IN HYDROGEN PEROXIDE DECOMPOSITION REACTION}

\author{
A.M. Grinko ${ }^{a, b,}$, , A.V. Brichka ${ }^{b}$, O.M. Bakalinska ${ }^{b}$, \\ O.I. Oranska ${ }^{b}$, M.T. Kartel ${ }^{b}$
}

a National University of «Kyiv-Mohyla Academy», Kyiv, Ukraine ${ }^{b}$ Chuiko Institute of Surface Chemistry of the National Academy of Sciences of Ukraine, Kyiv, Ukraine

*e-mail: alinagrinko2@gmail.com

A number of kaolin-based nanomaterials decorated with $\mathrm{CeO}_{2}$ were synthesized by the precipitation method from aqueous solutions of cerium nitrate, without stabilizers at room temperature, and their properties were characterized. The amount of nanoceria deposited in nanomaterials was 2.76-7.37\%, and their size varied from $5.6 \mathrm{~nm}$ to $10.4 \mathrm{~nm}$. X-ray diffraction analysis of the samples showed that cerium dioxide has a cubic structure. IR spectroscopy confirmed that a chemical interaction between the modifier and the matrix (i.e. the formation of a chemical bond) cannot be detected. The $\mathrm{Ce}^{4+} / \mathrm{Ce}^{3+}$ ratio in nanocomposites was estimated from $U V$-spectra of diffuse reflectance, it varied in the range of 0.98 to 2.88. By calculating the affinity constant from kinetic data in the framework of enzymatic reactions concept, the catalytic activity of the synthesized materials and kaolin in the model reaction of hydrogen peroxide decomposition was determined in the $\mathrm{pH}$ range of 8.5-10.5 and compared with the catalase enzyme and commercial nano-sized $\mathrm{CeO}_{2}$. The $\mathrm{pH}$ dependence of the nanocomposites activity was shown to be extreme with maxima at $\mathrm{pH}$ 10.0. The activation energy of the reaction of hydrogen peroxide decomposition on the studied catalysts was determined for the temperature range of $20^{\circ} \mathrm{C}$ to $40^{\circ} \mathrm{C}$ at $\mathrm{pH} 10.0$. It was found that the catalytic activity of nanocomposites increased and the activation energy decreased with an increase in the decorator content at a constant $\mathrm{pH}$. An analysis of the factors that determine the activity of nanoceria in the nanocomposites showed that an increase in the dispersion of nanocrystallites and the relative content of $\mathrm{Ce}^{3+}$ ions on their surface resulted in the improvement in the catalytic activity of nanomaterials.

Keywords: cerium oxide nanoparticles; kaolin; nanocomposites; catalytic activity; activation energy; hydrogen peroxide decomposition.

\section{REFERENCES}

1. Reed K., Cormack A., Kulkarni A., Mayton M., Sayle D., Klaessig F., Stadler B. Exploring the properties and applications of nanoceria: is there still plenty of room at the bottom? Environmental Science: Nano, 2014, vol. 1, no. 5, pp. 390-405.

2. Turkan I. ROS and RNS: key signaling molecules in plants. Journal of Experimental Botany, 2018, vol. 69, pp. 33133315 .

3. Baldim V., Bedioui F., Mignet N., Margaill I., Berret J.-F. The enzyme-like catalytic activity of cerium oxide nanoparticles and its dependency on $\mathrm{Ce}^{3+}$ surface area concentration. Nanoscale, 2018, vol. 10, pp. 6971-6980.
4. Pirmohamed T., Dowding J.M., Singh S., Wasserman B., Heckert E., Karakoti A.S., King J.E.S., Seal S., Self W.T. Nanoceria exhibit redox state-dependent catalase mimetic activity. Chemical Communications, 2010, vol. 46, pp. 2736-2738.

5. Mehmood R., Ariotti N., Yang J.L., Koshy P., Sorrell C.C. $\mathrm{pH}$-responsive morphology-controlled redox behavior and cellular uptake of nanoceria in fibrosarcoma. ACS Biomaterials Science \& Engineering, 2018, vol. 4, pp. 1064-1072.

6. Vinothkumar G., Arunkumar P., Mahesh A., Dhayalan A., Suresh Babu K. Size- and defect-controlled anti-oxidant enzyme mimetic and radical scavenging properties of cerium oxide nanoparticles. New Journal of Chemistry, 2018, vol. 42, pp. 1881018823.

7. Lin K.S., Chowdhury S. Synthesis, characterization, and application of 1-D cerium oxide nanomaterials: a review. International Journal of Molecular Sciences, 2010, vol. 11, pp. 3226-3251.

8. Korsvik C., Patil S., Seal S., Self W.T. Superoxide dismutase mimetic properties exhibited by vacancy engineered ceria nanoparticles. Chemical Communications, 2007, pp. 10561058 .

9. Nagiev T.M., Khimicheskoe sopryazhenie: sopryazhennye reaktsii okisleniya perekis'yu vodoroda [Chemical conjugation: conjugate hydrogen peroxide oxidations]. Nauka, Moscow, 1989. 216 p. (in Russian).

10. Xu L., Wang J. Magnetic nanoscaled $\mathrm{Fe}_{3} \mathrm{O}_{4} / \mathrm{CeO}_{2}$ composite as an efficient Fenton-like heterogeneous catalyst for degradation of 4-chlorophenol. Environmental Science \& Technology, 2012, vol. 46, pp. 10145-10153.

11. Wang G., Zhang J., He X., Zhang Z., Zhao Y. Ceria nanoparticles as enzyme mimetics. Chinese Journal of Chemistry, 2017, vol. 35, pp. 791-800.

12. Wei X., Li X., Feng Y., Yang S. Morphology- and $\mathrm{pH}$-dependent peroxidase mimetic activity of nanoceria. $R S C$ Advances, 2018, vol. 8, pp. 11764-11770.

13. Dmytrenko T.Yu., Kulyk K.S., Voitko K.V., Bakalinska O.N., Borysenko N.V., Kartel M.T. Catalytic activity of ceriumcontaining materials in reaction of hydrogen peroxide decomposition. Chemistry, Physics and Technology of Surface, 2014, vol. 5, no. 3, pp. 317-324.

14. Vlasova N.N., Golovkova L.P., Stukalina N.G. Adsorption of organic acids on a cerium dioxide surface. Colloid Journal, 2015, vol. 77, pp. 418-424.

15. Zhou X.D., Huebner W., Anderson H.U. Processing of nanometer-scale $\mathrm{CeO}_{2}$ particles. Chemistry of Materials, 2003, vol. 15 , pp. 378-382. 